OPEN ACCESS

Edited by:

Stelios Katsanevakis,

University of the Aegean, Greece

Reviewed by:

Jessica Miller,

Oregon State University,

United States

Audrey J. Geffen,

University of Bergen, Norway

${ }^{*}$ Correspondence:

María Eugenia Lattuca

elattuca@gmail.com

Specialty section:

This article was submitted to Marine Ecosystem Ecology,

a section of the journal

Frontiers in Marine Science

Received: 20 December 2019

Accepted: 14 May 2020

Published: 19 June 2020

Citation:

Lattuca ME, Llompart F

Avigliano E, Renzi M, De Leva I, Boy CC, Vanella FA, Barrantes ME,

Fernández DA and

de Albuquerque CQ (2020) First

Insights Into the Growth

and Population Structure of Cottoperca trigloides (Perciformes, Bovichtidae) From the Southwestern

Atlantic Ocean.

Front. Mar. Sci. 7:421.

doi: 10.3389/fmars.2020.00421

\section{First Insights Into the Growth and Population Structure of Cottoperca trigloides (Perciformes, Bovichtidae) From the Southwestern Atlantic Ocean}

\author{
María Eugenia Lattuca ${ }^{1 *}$, Facundo Llompart ${ }^{1,2}$, Esteban Avigliano ${ }^{3}$, Marta Renzi $^{4}$, \\ Ileana De Leva ${ }^{4}$, Claudia Clementina Boy ${ }^{1}$, Fabián Alberto Vanella ${ }^{1}$, \\ María Eugenia Barrantes ${ }^{1}$, Daniel Alfredo Fernández ${ }^{1,2}$ and \\ Cristiano Queiroz de Albuquerque 5
}

' Laboratorio de Ecología, Fisiología y Evolución de Organismos Acuáticos, Centro Austral de Investigaciones Cientificas (CADIC - CONICET), Ushuaia, Argentina, ${ }^{2}$ Instituto de Ciencias Polares, Ambiente y Recursos Naturales (UNTDF - ICPA), Universidad Nacional de Tierra del Fuego, Ushuaia, Argentina, ${ }^{3}$ Facultad de Ciencias Veterinarias - CONICET, Instituto de Investigaciones en Producción Animal (INPA, UBA - CONICET), Universidad de Buenos Aires, Buenos Aires, Argentina, ${ }^{4}$ Instituto Nacional de Investigación y Desarrollo Pesquero (INIDEP), Mar del Plata, Argentina, ${ }^{5}$ Departamento de Ciências Animais, Universidade Federal Rural do Semi-Arido (UFERSA), Mossoró, Brazil

The aim of this work was to describe the growth of Cottoperca trigloides, a notothenioid species with a non-Antarctic distribution, and to test the existence of different nursery areas and fish stocks through changes in the otolith elemental composition. Fish were collected during spring 2009 over the Patagonia continental shelf, including the Marine Protected Area Namuncurá/Burdwood Bank, in the southwestern Atlantic Ocean. The age and growth analyses were performed by counting marks in sagittae, assuming an annual periodicity of their deposition, and identified 8-year classes ( $0+$ to $7+$ ). Given the size range of the fish, length-at-age data were fitted to the Gompertz growth model $T L_{t}=55.45[\exp ((\exp )-0.32(t-1.89))]$, explaining more than 95\% of the growth pattern. Moreover, the chemical composition of otolith core and edge areas was analyzed by laser ablation inductively coupled plasma mass spectrometry. The canonical analysis of principal coordinates successfully allocated $72.92 \%$ of the fish for the core and $91.67 \%$ for the edge area of the otolith, in three groups corresponding to "northern Patagonia shelf," "southern Patagonia shelf," and "Marine Protected Area Namuncurá/Burdwood Bank" areas, suggesting a high segregation among them over the Patagonian shelf. Thus, otolith elemental composition has proven to be an efficient approach to identify different nursery areas and stocks for the species. The present results provide new information on the growth and the population structure of C. trigloides, from a geographical area where information on this issue is still scarce, constituting an essential tool to develop conservation principles for the species.

\section{Contribution INIDEP $\mathbf{N}^{\circ} 2211$}

Keywords: age determination, Cottoperca trigloides, fish stocks, growth, MPA Namuncurá/Burdwood Bank, nursery areas, otolith chemistry, southwestern Atlantic Ocean 


\section{INTRODUCTION}

Cottoperca trigloides (Forster, 1801) is the unique species of the family Bovichtidae (Balushkin, 2000; Eastman and Eakin ${ }^{1}$, version December 30,2019), the members of which are atypical notothenioids in having a largely non-Antarctic distribution (Eastman, 1993). This species has been reported from $41^{\circ}$ to $54^{\circ} \mathrm{S}$ over the southeastern Pacific and the southwestern Atlantic Oceans (the Patagonian region of Chile and Argentina), including the Strait of Magellan, the Beagle Channel, the Burdwood Bank, the Staten Island, and the Malvinas/Falklands Islands (Lloris and Rucabado, 1991; Fernández et al., 2009). Although its bathymetric distribution was indicated between 10 and $270 \mathrm{~m}$ depth (Lloris and Rucabado, 1991), Laptikhovsky and Arkhipkin (2003) also pointed out that C. trigloides is commonly found between 150 and $400 \mathrm{~m}$, in the outer shelf and slope around the Malvinas/Falklands Islands. According to the fishery statistics of these islands, the incidental catch of the species was 48.4 tons during 2018 (Falkland Islands Government [FIG], 2019). Despite its abundance and its quite remarkable bycatch during finfish and squid trawl fishing, data on its biology are still scarce. To date, it is known that $C$. trigloides is a benthic ambush predator, feeding mainly on fish, small crustaceans, and algae (Moreno and Jara, 1984; Matallanas, 1988; Lloris and Rucabado, 1991; Laptikhovsky and Arkhipkin, 2003). Arkhipkin et al. (2015) also described the spawning and early ontogeny of the species under captivity conditions, indicating that mature males and females attain $50-80 \mathrm{~cm}$ and $40-60 \mathrm{~cm}$ total length, respectively, and that the species has high fecundity and growth rates, enabling it to occupy large areas of the Patagonian Shelf. Additionally, studies performed in the Beagle Channel indicated that $C$. trigloides lives in association with the holdfast of Macrocystis pyrifera kelp forest (Vanella et al., 2007), in accordance with their low buoyancy (Fernández et al., 2012). In those ecosystems, Fernández et al. (2018) described an isometric growth for the species, without intersex differences in the slope for the length-weight relationships. Moreover, Fernández et al. (2009) determined the energy content of C. trigloides, obtaining the lowest value (21.82 $\mathrm{kJ} \mathrm{g}^{-1}$ dry weight) among different notothenioid species. Although its physiology has not been studied in detail, as a temperate species, it is ideal for assessing the evolution and functional importance of biochemical adaptations to temperature (Giordano et al., 2008; Coppola et al., 2010). Much work has been done related to the biogeography (Balushkin, 2000; Colombo et al., 2015; Papetti et al., 2016) and morphology (Iwami, 2004; Eastman et al., 2014) of the notothenioid fish, as they were the main object of large-scale fisheries during the past three decades. Thus, at present there is an important stimulus to study the life history traits and the ecology of $C$. trigloides to protect and apply conservation principles to the species.

Otolith chemical composition has proven quite useful for managing and understanding the ecology of several marine and freshwater fish populations in recent years (Catalán et al., 2018; Radigan et al., 2018; Avigliano et al., 2019; Soeth et al., 2019). Otoliths are calcified structures, located in the inner ear of teleost

${ }^{1}$ https://people.ohio.edu/eastman/ fish, that are composed mainly of aragonite (calcium carbonate, $\sim 96 \%$ ) deposited in an acellular matrix (Campana, 1999). Since the structure of fish otoliths is acellular and metabolically inert, once elements are incorporated from the endolymphatic fluid, their concentrations remain fixed over the life of the fish (Thomas et al., 2017; Thomas and Swearer, 2019). Thus, they can function as natural tags that provide information on life history and population structure of fish (Walther and Limburg, 2012; Tanner et al., 2016; Avigliano et al., 2018a). There are different mechanisms for the incorporation of trace elements in otoliths, such as calcium substitution, in which some divalent ions are incorporated in the substitution to calcium $\left(\mathrm{Ca}^{2+}\right)$ into the otolith carbonatic matrix, and random trapping of free ions (Thomas and Swearer, 2019). For the elements that substitute for $\mathrm{Ca}$, there may be some proportion with its environmental availability, while for the elements that do not replace $\mathrm{Ca}$, the relationships with the environment are less clear (Thomas et al., 2017; Thomas and Swearer, 2019).

By tracking changes in elemental concentrations over time in an individual fish or among fish captured from different locations, it is often possible to deduce much about their environmental history, such as the previous habitat uses, stock compositions, and nursery locations (Thresher, 1999; Brazner et al., 2004; Avigliano et al., 2018b; Soeth et al., 2019). In recent years, otolith chemical composition has been applied to the study of small pelagic (Mai et al., 2014; Carvalho et al., 2017) and demersal (Volpedo and Fernández Cirelli, 2006; Albuquerque et al., 2012; Avigliano et al., 2017a) fish in the southwestern Atlantic Ocean. Moreover, this technique resolved the population structure of some notothenioid species, such as the Patagonian toothfish Dissostichus eleginoides (Smitt, 1898) (Ashford et al., 2005, 2006), and the Scotia Sea icefish Chaenocephalus aceratus (Lönnberg, 1906) (Ashford et al., 2010) successfully. Previously, Radtke and Targett (1984) and Radtke et al. (1993) also employed otolith chemical analyses to characterize the environmental life history of two Antarctic fish, Notothenia larseni (Lönnberg, 1905) and Pleuragramma antarcticum (Boulenger, 1902).

In line with previous studies, we aimed to describe the growth of an extra-Antarctic notothenioid species, C. trigloides, and to test the existence of different nursery areas and fish stocks, corresponding to the "northern Patagonia shelf," "southern Patagonia shelf," and "Marine Protected Area (MPA) Namuncurá/Burdwood Bank" areas along the southwestern Atlantic Ocean, by using otolith chemistry. The present results represent the first data on the growth and the population structure of $C$. trigloides, from a geographical area where information on the subject is still scarce, constituting an essential tool to develop conservation strategies to the species.

\section{MATERIALS AND METHODS}

\section{Ethics Statement}

Cottoperca trigloides is not protected under wildlife conservation laws (local legislations, International Union for Conservation of Nature [IUCN], or Convention on International Trade in Endangered Species [CITES]). Individuals employed in this 
study were captured within the framework of the Pampa Azul interministerial initiative, promoted by the Ministerio de Ciencia, Tecnología e Innovación Productiva. As the Consejo Nacional de Investigaciones Cientificas y Técnicas (CONICET) does not possess formal Committees regarding the fish welfare and sampling protocols, fish handling during sampling was performed following guidelines of the ethical committee of the Universities Federation for Animal Welfare (UFAW) Handbook on the Care and Management of Laboratory Animals².

\section{Fish Sampling and Processing}

Fish were collected during November-December 2009 from the Oceanographic Vessel Puerto Deseado of the Consejo Nacional de Investigaciones Científicas y Técnicas (CONICET, Argentina) over the Patagonia continental shelf (PS) in the southwestern Atlantic Ocean $\left(41^{\circ} 16^{\prime}-55^{\circ} 03^{\prime} \mathrm{S}\right.$ and $\left.57^{\circ} 22^{\prime}-68^{\circ} 15^{\prime} \mathrm{W}\right)$, including the Burdwood Bank $\left(55^{\circ} \mathrm{S}, 59^{\circ} \mathrm{W}\right)$ (Figure 1). This latter area is a shallow seamount located in the northeastern portion of the Drake Passage. It has been recently declared a marine sanctuary, since it constitutes a highly productive ecosystem and an important migration destination for a wide variety of seabirds and marine mammals (Namuncurá Marine Protected Area; Schetjer et al., 2016).

Along the "northern Patagonia shelf" (NPS), "southern Patagonia shelf" (SPS), and "MPA Namuncurá/Burdwood Bank" (BB) areas, which were defined according to the circulation patterns observed over the PS, C. trigloides individuals were collected at 11 sampling stations employing a demersal bottom trawl pilot net $(6 \mathrm{~m}$ total length, $25 \mathrm{~mm}$ mesh on the wings and $10 \mathrm{~mm}$ in the cod end, $0.6 \mathrm{~m}$ vertical opening and $1.8 \mathrm{~m}$ horizontal aperture). Hauls were performed during the day and night, with a target time of $15 \mathrm{~min}$ and a tow speed between 2 and 3.7 knots. Individuals captured in station nos. 1, 2, 3, 7 , and 8 were assigned to the NPS group, individuals from station nos. $12,13,15,16$, and 18 composed the SPS group, and those from station 17 were included in the BB group. The sampling stations with no $C$. trigloides captures $(4,5,6,10,14,19,20)$ were not included in the analyses. Fish were counted and identified following Gon and Heemstra (1990) and specific taxonomic articles. Individual $C$. trigloides were measured to total length $(T L, \pm 0.1 \mathrm{~mm})$ and sexed when possible, since gonads of some individuals were indistinguishable. The sagittae were extracted, cleaned mechanically with distilled water, and stored dry.

Moreover, a Seabird SBE 21 thermosalinograph was used to measure the sea surface temperature and salinity and an echosounder Monhaz was used to measure depth.

\section{Age and Growth Analysis}

The right otoliths of 141 C. trigloides individuals (84-510 mm TL) were embedded in crystal polyester resin and cut transversally through the core using a low-speed, diamond blade IsoMet ${ }^{\mathrm{TM}}$ LS saw. The number, width, and radius of each mark and otolith radius $(O R)$ were recorded, along the longest axis of the transverse section, under an Olympus SZH10 stereomicroscope $(10 \times)$ and an image analysis system (Otoli 32 ). The average

${ }^{2}$ http://www.ufaw.org.uk percent error (APE, Beamish and Fournier, 1981) and the coefficient of variation (CV, Chang, 1982; Campana, 2001) were used to determine the precision level of age interpretations.

Because it was not possible to validate the periodicity of growth mark deposition in otoliths for $C$. trigloides, an annual periodicity was assumed according to the observations performed in other notothenioid species such as Eleginops maclovinus (Cuvier and Valenciennes, 1830) (Brickle et al., 2005; Licandeo et al., 2006) and Patagonotothen ramsayi (Regan, 1913) (Brickle et al., 2006).

After verifying linearity between $O R$ and $T L$, the Fraser-Lee procedure (Campana, 1990) was used to back-calculate TL of each fish at past ages according to

$$
T L_{a}=b+(T L-b) O R^{-1} O R_{a}
$$

where $T L_{a}$ and $O R_{a}$ are the fish total length $(\mathrm{cm})$ and otolith radius $(\mu \mathrm{m})$ at some previous age $a, T L$ and $O R$ are the fish total length $(\mathrm{cm})$ and otolith radius $(\mu \mathrm{m})$ at capture, and $b$ is the intercept of the linear regression between $O R$ and $T L$.

Annual growth rates were calculated as

$$
G R=T L_{i}-T L_{i-1}
$$

where $G R$ is the individual growth rate $\left(\mathrm{cm} \mathrm{year}^{-1}\right), T L_{i}$ is the total length of fish back-calculated at age $i$, and $T L_{i-1}$ is the total length of fish back-calculated at age $i-1$.

Differences in $T L$ and $G R$ at previous ages were evaluated with one-way repeated measures analysis of variance (RM ANOVA) followed by pairwise multiple comparison procedures (HolmSidak test). Sphericity was previously assessed using the Mauchly test. The statistical decisions were based on $\alpha=0.05$ (Zar, 1984; Sokal and Rohlf, 2011).

Moreover, $T L$ at first maturity was estimated following Froese and Binohlan (2000), who proposed the following equations:

Females: $\log T L_{m}=0.9469 \log T L_{\infty}-0.1162$

Males: $\log T L_{m}=0.8915 \log T L_{\infty}-0.1032$

where $T L_{m}$ is the total length at maturity and $T L_{\infty}$ is derived from

$$
T L_{\infty}=0.044+0.9841 T L_{\max }
$$

where $T L_{\max }$ is the maximum total length of the species. $T L_{\max }$ values used ( $80 \mathrm{~cm}$ for males and $60 \mathrm{~cm}$ for females) are those reported by Arkhipkin et al. (2015).

According to the size range of $C$. trigloides present in the samples and the low percent of mature individuals (7.2\%) resulting from previous equations, the Gompertz function was chosen to model the growth of the species, as it is more appropriate in describing the growth of juvenile fish (Ricker, 1979). Thus, length-at-age data were fitted to the following equation:

$$
T L_{t}=T L_{\infty} e\left[e^{-k(t-\mathrm{I})}\right]
$$

where $T L_{t}$ is the total length at age $t, T L_{8}$ represents the asymptotic total length, $k$ is the growth rate, $t$ is the age, and $I$ is the age at the inflection point (Gompertz, 1825). Owing to the low number of individuals, no distinctions between sexes 


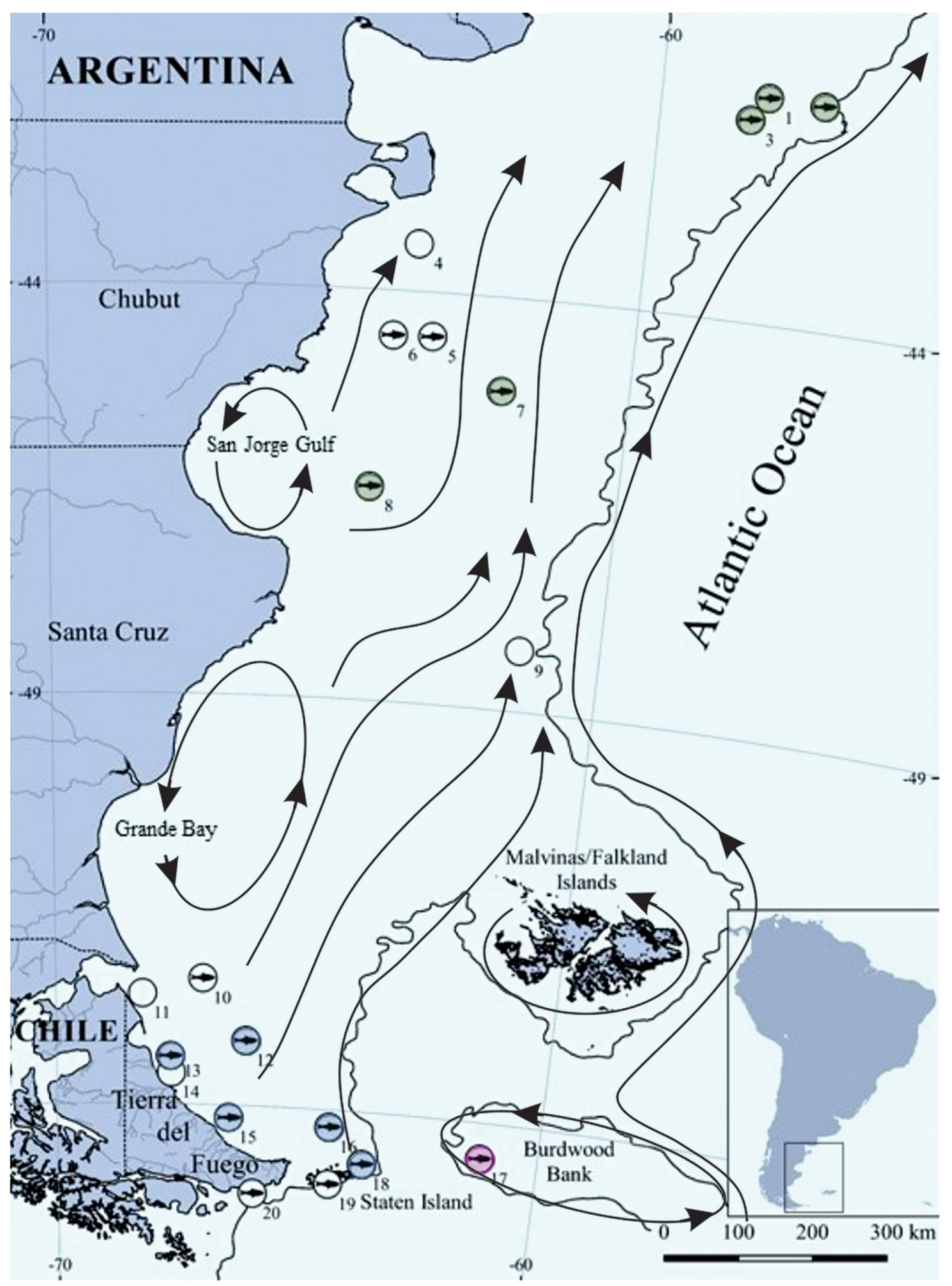

FIGURE 1 | Study area and sampling stations during November-December 2009 in the southwestern Atlantic Ocean. The solid black line represents the $200 \mathrm{~m}$ isobath, circles with a fish represent stations where $C$. trigloides was captured and empty circles represent stations where $C$. trigloides was not captured. Different colors indicate different geographic areas (NPS: northern Patagonia shelf, green; SPS: southern Patagonia shelf, blue; and BB: Burdwood Bank, pink). Stations without colors were not included in elemental analyses. Black arrows represent main currents over the PS according Palma et al. (2008). 
or capture areas were made to fit the model. The estimates of the parameters of the model were performed using the program Growth II (Henderson and Seaby, 2006).

\section{Elemental Analysis}

Because the otolith material is continuously deposited and not reabsorbed (Campana, 1999; Takagi and Takahashi, 1999), the otolith core chemistry, which corresponds to the early stage of life, is a useful spawning or nursery area natural marker. On the other hand, the outer area composition, which represents the last time of life, is often used as a stock indicator (Campana, 2014; Avigliano et al., 2017b; Biolé et al., 2019). Thus, the chemical compositions of the otolith core and edge were analyzed separately to evaluate differences in the stocks and nursery structure of $C$. trigloides between NPS, SPS, and BB areas.

Transverse sections $(400 \mu \mathrm{m})$ of the left otoliths $\left(N_{\text {total }}=48\right.$, $N_{N P S}=12, N_{S P S}=30, N_{B B}=6 ; 119-475 \mathrm{~mm} \mathrm{TL}$ ) were mounted onto glass slides with cyanoacrylic glue. Otolith surfaces were polished with silicon carbide paper (no. 8000), washed with Milli-Q water (resistivity of $18.2 \mathrm{mOhm} \mathrm{cm} \mathrm{cm}^{-1}$, Millipore, Bedford, MA, United States), and ultrasonically cleaned (3 min), followed by rinsing with Milli-Q water. The slides were then dried in a laminar flow cabinet before chemical analysis.

Elements $\mathrm{Ca}, \mathrm{Sr}, \mathrm{Mg}, \mathrm{Mn}, \mathrm{Ba}$, and $\mathrm{Pb}$ were measured by laser ablation inductively coupled plasma mass spectrometry (LA-ICP-MS) in Pontificia Universidad Católica (Río de Janeiro, Brazil). Two radial line-scans were ablated separately in the otolith core and edge. These areas represent approximately the entire core area (nursery area indicator, $1338 \pm 247 \mu \mathrm{m}$ ) and the last (stock indicator, $296 \pm 74 \mu \mathrm{m}$ ) complete annuli. A Q-switched pulsed $266 \mathrm{~nm}$ Nd:YAG laser (LSX 100, CETAC Technologies Inc., Omaha, NE, United States) coupled to an ELAN 6000 ICPMS (PerkinElmer-SCIEX, Waltham, MA, United States) was used to analyze C. trigloides otoliths. The laser was set up with a scan speed of $20 \mu \mathrm{m} / \mathrm{s}$, a pulse frequency of $20 \mathrm{~Hz}$, and an energy output of $0.4-0.6 \mathrm{~mJ}$ per pulse. This setup resulted in a $\sim 25 \mu \mathrm{m}$ crater width. Laser and ICP-MS were linked through a Teflon-coated tube, using argon as carrier gas $\left(0.85 \mathrm{dm}^{3} \mathrm{~min}^{-1}\right)$. The ICP-MS power was set at $1500 \mathrm{~W}$, with an outer and intermediate gas flow of 15 and $1.1 \mathrm{dm}^{3} \mathrm{~min}^{-1}$, respectively. Before the analysis, the ICP-MS was optimized using the Daily Performance tool, with maximum analytic intensities and minimum interferences determined using oxides and double-charged ions. The samples were randomly analyzed to avoid systematic bias through the analytical session. Moreover, Ca was used as an internal standard to correct for the elemental fractionation caused by sensitivity drift, differences in ablation yield, and matrix effect (Jackson, 2008; Lin et al., 2016). Standardization to otolith $\mathrm{Ca}$ is used in otolith chemical analyses for reducing intersample variance because it is the major element and is relatively invariant (Campana et al., 1997). Furthermore, the reference material NIST1834 (National Institute of Standards and Technology, Gaithersburg, MD, United States), which was certified for Ba, $\mathrm{Ca}, \mathrm{Mg}$, and Sr (NIST, 1990), was measured as external standard 10 times among the 48 samples analyzed. The relative standard deviation (RSD,\%) between the NIST1834 measurements was $2.4 \%$ for $\mathrm{Ba}, 4 \%$ for $\mathrm{Sr}, 7 \%$ for $\mathrm{Mn}$, and $9.5 \%$ for $\mathrm{Mg}$, which indicated acceptable repeatability and low drift throughout the analytical session. The values obtained in both the otoliths and NIST1834 were systematically above the limit of detection (LOD), which was calculated from the gas blank before laser ignition (Geffen et al., 2013) as the mean element:Ca ratio plus 3 standard deviations of the background. LODs were $0.058,0.096,0.278$, and 0.042 for Ba:Ca, Mg:Ca, Mn:Ca, and Sr:Ca, respectively. Element counts per second (cps) were subtracted from the background level, and element:Ca ratios were then calculated for core and edge transects separately.

Otolith chemical composition was simplified and only the four most informative variables were retained $(\mathrm{Ba}: \mathrm{Ca}, \mathrm{Mg}: \mathrm{Ca}$, $\mathrm{Mn}: \mathrm{Ca}$, and $\mathrm{Sr}: \mathrm{Ca})$ and were $\log \left(x^{*} 1000\right)$ transformed to balance their influence. The comparisons of these elemental ratios among geographic areas were made with one-way analysis of variance (ANOVA) or Kruskal-Wallis one-way analysis of variance on ranks (Kruskal-Wallis), followed by pairwise multiple comparison procedures (Tukey test or Dunn's test). The assumptions of normality and homoscedasticity were evaluated through Shapiro-Wilks and Levene tests, respectively. All statistical decisions were based on $\alpha=0.05$ (Zar, 1984; Sokal and Rohlf, 2011). Moreover, as the growth rate can affect the incorporation of trace elements into the otolith, the effect of size on the elemental ration was tested using Spearman's rank-order correlation (Biolé et al., 2019).

In the following analyses, the existence of different nursery areas and stocks of $C$. trigloides between geographic areas along the southwestern Atlantic Ocean was tested. For each area of the otolith, a Euclidean distance matrix was constructed using the log-transformed elemental ratios. A one-way non-parametric permutational multivariate analysis of variance (PERMANOVA) was performed to determine whether significant differences exist in the chemical composition of fish grouped by geographical areas (NPS, SPS, and BB) for both the otolith core and edge. The responsible elements for the intragroup similarity were assessed through a percentage of similarity analysis (SIMPER). The resemblance matrix was further employed in a canonical analysis of principal coordinates (CAP) to visualize the spatial variability of the otolith chemical composition and to measure the degree of fish allocation success within the geographical groups. All the multivariate analyses were performed using the statistical package PRIMER v7 (Anderson et al., 2008; Clarke et al., 2014).

\section{RESULTS}

Environmental characteristics regarding depth, salinity, and temperature, of each sampling station over the PS in the southwestern Atlantic Ocean are shown in Table 1. Between $41^{\circ}$ and $54^{\circ} \mathrm{S}$, salinity values were quite similar and ranged from 32.5 (station 11) to 34.0 (station 17). On the other hand, temperature values were more variable, ranging between $5.43^{\circ} \mathrm{C}$ (station 17) and $12.50^{\circ} \mathrm{C}$ (station 4 ); this variability was associated not only with latitude but also with depth. 
TABLE 1 | Location of sampling stations, environmental factors measured, and the number of C. trigloides captured in the southwestern Atlantic Ocean.

\begin{tabular}{|c|c|c|c|c|c|c|}
\hline Sampling station & Latitude (S) & Longitude (W) & Depth (m) & Salinity & Temperature $\left({ }^{\circ} \mathrm{C}\right)$ & C. trigloides (n) \\
\hline 1 & $41^{\circ} 16^{\prime} 12^{\prime \prime}$ & $58^{\circ} 16^{\prime} 48^{\prime \prime}$ & 78 & 33.5 & 8.14 & 1 \\
\hline 2 & $41^{\circ} 17^{\prime} 24^{\prime \prime}$ & $57^{\circ} 22^{\prime} 48^{\prime \prime}$ & 123 & 33.6 & 5.70 & 2 \\
\hline 3 & $41^{\circ} 33^{\prime} 36^{\prime \prime}$ & $58^{\circ} 32^{\prime} 24^{\prime \prime}$ & 137 & 33.6 & 6.9 & 6 \\
\hline 4 & $43^{\circ} 25^{\prime} 29^{\prime \prime}$ & $63^{\circ} 45^{\prime} 29^{\prime \prime}$ & 76 & 33.5 & 12.5 & 0 \\
\hline 5 & $44^{\circ} 32^{\prime} 24^{\prime \prime}$ & $63^{\circ} 25^{\prime} 48^{\prime \prime}$ & 83 & 33.6 & 7.25 & 1 \\
\hline 6 & $44^{\circ} 33^{\prime} 00^{\prime \prime}$ & $64^{\circ} 06^{\prime} 00^{\prime \prime}$ & 86 & 33.6 & 7.19 & 1 \\
\hline 7 & $45^{\circ} 08^{\prime} 24^{\prime \prime}$ & $62^{\circ} 11^{\prime} 24^{\prime \prime}$ & 85 & 33.7 & 6.31 & 3 \\
\hline 8 & $46^{\circ} 23^{\prime} 59^{\prime \prime}$ & $64^{\circ} 21^{\prime} 27^{\prime \prime}$ & 113 & 33.1 & 9.64 & 5 \\
\hline 9 & $48^{\circ} 15^{\prime} 41^{\prime \prime}$ & $61^{\circ} 27^{\prime} 08^{\prime \prime}$ & 175 & 33.6 & 7.78 & 0 \\
\hline 10 & $52^{\circ} 27^{\prime} 55^{\prime \prime}$ & $67^{\circ} 03^{\prime} 58^{\prime \prime}$ & 96 & 33.1 & 6.66 & 1 \\
\hline 11 & $52^{\circ} 39^{\prime} 29^{\prime \prime}$ & $68^{\circ} 15^{\prime} 57^{\prime \prime}$ & 71 & 32.5 & 6.97 & 0 \\
\hline 12 & $53^{\circ} 12^{\prime} 38^{\prime \prime}$ & $66^{\circ} 09^{\prime} 52^{\prime \prime}$ & 103 & 33.0 & 7.09 & 21 \\
\hline 13 & $53^{\circ} 25^{\prime} 09^{\prime \prime}$ & $67^{\circ} 41^{\prime} 04^{\prime \prime}$ & 54 & 32.6 & 6.34 & 11 \\
\hline 14 & $53^{\circ} 37^{\prime} 13^{\prime \prime}$ & $67^{\circ} 39^{\prime} 31^{\prime \prime}$ & 46 & 32.6 & 7.56 & 0 \\
\hline 15 & $54^{\circ} 09^{\prime} 08^{\prime \prime}$ & $66^{\circ} 27^{\prime} 35^{\prime \prime}$ & 65 & 32.7 & 6.88 & 24 \\
\hline 16 & $54^{\circ} 12^{\prime} 33^{\prime \prime}$ & $64^{\circ} 22^{\prime} 17^{\prime \prime}$ & 121 & 33.7 & 5.86 & 8 \\
\hline 17 & $54^{\circ} 26^{\prime} 05^{\prime \prime}$ & $61^{\circ} 11^{\prime} 48^{\prime \prime}$ & 97 & 34.0 & 5.43 & 11 \\
\hline 18 & $54^{\circ} 37^{\prime} 57^{\prime \prime}$ & $63^{\circ} 38^{\prime} 23^{\prime \prime}$ & 88 & 33.2 & 6.32 & 33 \\
\hline 19 & $54^{\circ} 54^{\prime} 08^{\prime \prime}$ & $64^{\circ} 19^{\prime} 19^{\prime \prime}$ & 145 & 33.2 & 6.34 & 3 \\
\hline 20 & $55^{\circ} 03^{\prime} 44^{\prime \prime}$ & $65^{\circ} 53^{\prime} 59^{\prime \prime}$ & 125 & 32.9 & 6.74 & 10 \\
\hline
\end{tabular}

\section{Age and Growth Analysis}

The age and growth analysis of the species was performed by counting annual marks in sagittae. These otoliths showed complex patterns of growth mark formation, making them difficult to read. However, the simple regression analysis $\left(R^{2}=0.81, p<0.001\right)$ showed an agreement between the two readers. Moreover, the values from both the APE $(2.58 \%)$ and the CV (3.65\%) indicated a good level of precision for readings. The count of annual marks allowed identifying 8-year classes, being the ages of individual $C$. trigloides ranging between $0+$ and $7+$. While the $0+$ year class was the least represented $(0.71 \%)$, the $1+$ and $2+$ year classes were dominant (22.70 and $31.21 \%$, respectively). Furthermore, the ages of male individuals ( $20 \%$ of total capture) were between $1+$ and $7+$, and those of females ( $41 \%$ of total capture) between $1+$ and $5+$. The ages of the remaining unsexed individuals (39\% of the capture) were between $1+$ and $4+$.

The relationship between $O R$ and $T L$ can be expressed as follows, $T L=8.618+0.0135$ OR $\left(R^{2}=0.807, p<0.001\right)$. Mean back-calculated $T L$ by sex are shown in Table 2. Sizes at previous ages were significantly different only for ages 3 (RM ANOVA, $F=5.179, p=0.009)$ and 4 (RM ANOVA, $F=6.711, p=0.017)$, with males larger than females and unsexed fish. The GR was individually estimated based on back-calculated TL (Table 3). Mean GR showed significantly larger values for males at previous ages 2 (RM ANOVA, $F=7.238, p=0.002$ ) and 3 (RM ANOVA, $F=11.063, p=0.003)$.

Considering the $T L_{\max }$ values reported for males $(50-80 \mathrm{~cm})$ and females $(40-60 \mathrm{~cm})$ of $C$. trigloides (Arkhipkin et al., 2015) and following Froese and Binohlan (2000), the $T L_{\max }$ of males and females of the species was estimated at 40.3 and $38.2 \mathrm{~cm}$, respectively. These values indicated that few mature individuals
TABLE 2 | Back-calculated total length (TL, mean \pm standard deviation) for past ages of $C$. trigloides from the southwestern Atlantic Ocean.

\begin{tabular}{lrrr}
\hline Past ages (years) & \multicolumn{3}{c}{ Back-calculated $\boldsymbol{T L}(\mathbf{c m})$} \\
\cline { 2 - 4 } & \multicolumn{1}{c}{ Unsexed } & \multicolumn{1}{c}{ Males } & \multicolumn{1}{c}{ Females } \\
\hline 1 & $8.77 \pm 2.92^{\mathrm{a}}$ & $9.35 \pm 2.87^{\mathrm{a}}$ & $9.39 \pm 3.07^{\mathrm{a}}$ \\
2 & $16.52 \pm 3.33^{\mathrm{a}}$ & $18.38 \pm 3.60^{\mathrm{a}}$ & $17.47 \pm 3.29^{\mathrm{a}}$ \\
3 & $22.16 \pm 3.96^{\mathrm{a}}$ & $25.94 \pm 4.05^{\mathrm{b}}$ & $23.50 \pm 3.88^{\mathrm{a}}$ \\
4 & & $32.13 \pm 4.88^{\mathrm{a}}$ & $29.10 \pm 4.25^{\mathrm{b}}$ \\
5 & & $38.11 \pm 4.54$ & \\
6 & & $42.77 \pm 3.28$ & \\
\hline
\end{tabular}

Different letters indicate significant differences between sexes.

(8 males and 2 females) were present in the total capture and that most of the fish were juveniles. Therefore, pooled length-at-age data were used to fit the Gompertz growth model for C. trigloides from the southwestern Atlantic Ocean (Figure 2). The estimated parameters and their $95 \%$ confidence intervals are: $T L_{8}=52.85$ (52.13-53.57), $k=0.33(0.03-0.63)$, and $I=2.04$ ( -0.35 to 4.43$)$. Sample sizes did not allow growth comparison between sexes or among capture areas.

\section{Elemental Analysis}

No significant relationships were detected between the four elemental ratios in the otolith core or edge and fish size (Spearman's correlation, $0.0343<r_{S}<0.284 ; 0.169<p<0.816$ ); therefore, it was not necessary to make any correction on the original variables.

Comparisons of element:Ca ratios at the otolith core and edge for the different geographic areas are shown in Figure 3. For the otolith core, significant differences in $\mathrm{Ba}: \mathrm{Ca}$ (Kruskal-Wallis, 
TABLE 3 | Annual growth rates (GR, mean \pm standard deviation) for past ages of C. trigloides from the southwestern Atlantic Ocean.

\begin{tabular}{lccc}
\hline Past ages (years) & \multicolumn{3}{c}{ GR (cm year ${ }^{-\mathbf{1}}$ ) } \\
\cline { 2 - 4 } & Unsexed & Males & Females \\
\hline 1 & $7.74 \pm 2.78^{\mathrm{a}}$ & $9.02 \pm 2.91^{\mathrm{a}}$ & $8.11 \pm 3.14^{\mathrm{a}}$ \\
2 & $4.76 \pm 2.40^{\mathrm{a}}$ & $7.48 \pm 2.15^{\mathrm{b}}$ & $5.58 \pm 2.13^{\mathrm{a}}$ \\
3 & & $6.35 \pm 1.95^{\mathrm{a}}$ & $4.54 \pm 1.60^{\mathrm{b}}$ \\
4 & & $4.47 \pm 1.75$ & \\
5 & & $2.73 \pm 0.73$ & \\
\hline
\end{tabular}

Different letters indicate significant differences between sexes.

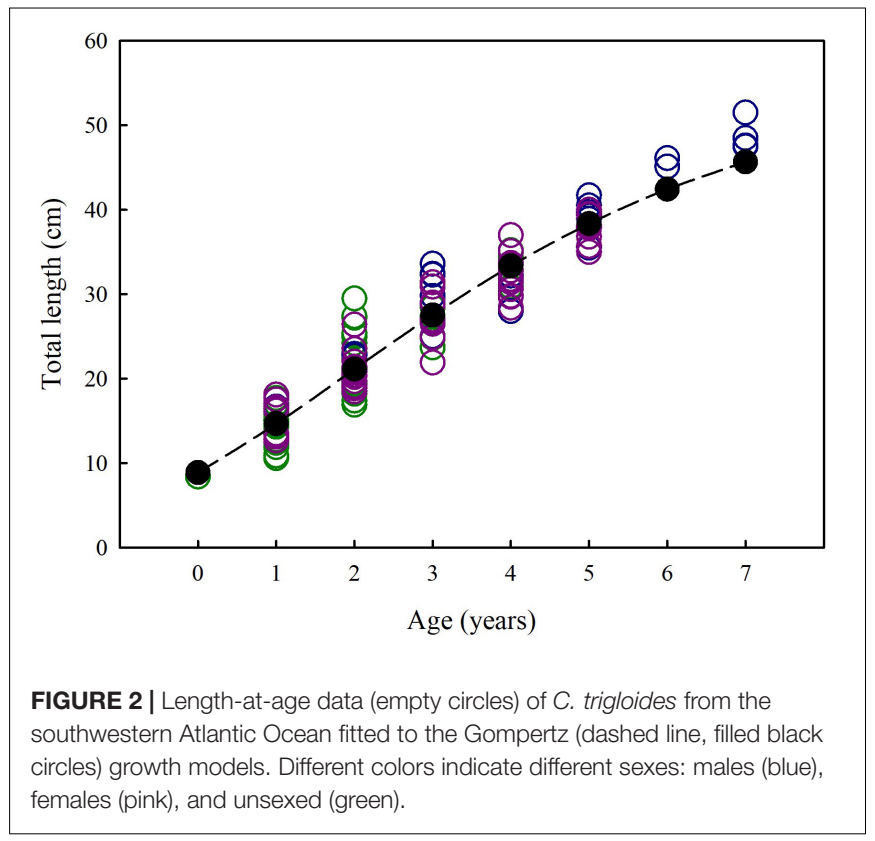

$H=10.094, p=0.006)$ and $\mathrm{Mn}: \mathrm{Ca}$ ratios were found (KruskalWallis, $H=21.407, p=0.001$ ). Fish from BB showed lower values as compared to NPS and SPS (Dunn's tests, $p<0.05$ ). No significant differences in $\mathrm{Mg}$ : $\mathrm{Ca}$ (Kruskal-Wallis, $H=3.615$, $p=0.164$ ) and Sr:Ca (Kruskal-Wallis, $H=2.737, p=0.254$ ) ratios were found among geographic areas. For the otolith edge, Ba:Ca (Kruskal-Wallis, $H=7.954, p=0.019$ ) and Sr:Ca (ANOVA, $F=5.948, p=0.005)$ ratios differed significantly, and multiple comparison tests showed that values registered in $\mathrm{BB}$ were higher than those of NPS and SPS (Ba:Ca, Dunn's test, $p<0.05$; $\mathrm{Sr}: \mathrm{Ca}$ : Tukey test, $p<0.05$ ). The Mn:Ca (Kruskal-Wallis, $H=2.180$, $p=0.336)$ and Mg:Ca (Kruskal-Wallis, $H=5.473, p=0.065$ ) ratios did not differ among geographic areas.

Moreover, the concentration of the four element:Ca ratios among all areas were statistically different for the core (PERMANOVA, BB vs. SPS, $p=0.0007$; BB vs. NPS, $p=0.0003$ and SPS vs. NPS, $p=0.0005$ ) and edge (PERMANOVA, $\mathrm{BB}$ vs. SPS, $p=0.0001 ; \mathrm{BB}$ vs. NPS, $p=0.0002$ and SPS vs. NPS, $p=0.0001$ ) areas. Thus, these analyses proved the existence of three different groups of $C$. trigloides individuals that corresponded to NPS, SPS, and BB areas. In addition, for both otolith areas, the SIMPER analyses indicated that $\mathrm{Mn}: \mathrm{Ca}$,
$\mathrm{Mg}: \mathrm{Ca}$, and $\mathrm{Ba}: \mathrm{Ca}$ ratios were the element:Ca ratios that most accounted for the intragroup similarity of the three major groups of C. trigloides individuals identified (Table 4). Although the variabilities of the chemical composition (four element:Ca ratios) in the otolith core and the edge area were analyzed separately, they generated similar spatial arrangements (Figures 4, 5). The CAP analyses, constrained by geographical arrangement, was able to successfully allocate a $72.92 \%$ of the fish for the core area (NPS: $84.62 \%$, SPS: $65.52 \%$, and BB: $83.33 \%$ ) and $91.67 \%$ for the edge area of the otolith (NPS: $100 \%$, SPS: $86.67 \%$, and BB: $100 \%$ ).

\section{DISCUSSION}

\section{Age and Growth Analysis}

The present study describes, for the first time, the age and growth of C. trigloides from the southwestern Atlantic Ocean. Although their sagittae showed a complex pattern of growth mark formation, age estimates were precise enough, suggesting that these otoliths were appropriate structures for the age estimation of the species. According to the available information in the literature related to the growth of different notothenioid species, an annual growth mark deposition was assumed on these otoliths (Brickle et al., 2005, 2006; Licandeo et al., 2006). This fact was due to the absence of the necessary samples to verify the periodicity of mark formation in the present samples, given that the sampling program performed included many stations but in a limited period.

Cottoperca trigloides captured between $41^{\circ}$ and $54^{\circ} \mathrm{S}$ of the southwestern Atlantic Ocean, with sizes ranging from 8.4 to $51.5 \mathrm{~cm} \mathrm{TL}$, belonged to 8-year classes, and $92.8 \%$ of them were juveniles. In this regard, Lobao-Tello and Hüne (2012) mentioned that $C$. trigloides less than $55 \mathrm{~cm} T L$ are the most frequent individuals in wild populations, in agreement with the size range registered by Vanella et al. (2007) and Fernández et al. (2012, 2018). The lack of older fish in the capture restricted the ages to a narrow range that is functionally linear and makes it difficult to fit a non-linear function, especially those with a horizontal asymptote. In consequence, the Gompertz growth function was fitted, being more appropriate for this type of data. This model described the growth of the species adequately, with an estimated $T L \infty(52.85 \mathrm{~cm})$ quite similar to that of the larger fish $(51.5 \mathrm{~cm})$ registered in the samples and a large $k$ value $(0.33)$ that reflected the typically fast growth observed in juvenile fish. Moreover, the back-calculation of $T L$ at previous ages revealed some growth differences related to sex. Cottoperca trigloides males attained larger $T L$ than females and exhibited faster growth rates since the age of 2 years. Given that the growth of some notothenioid fish from the sub-Antarctic area has been described through the von Bertalanffy growth model (Brickle et al., 2005, 2006; Licandeo et al., 2006), it was not possible to make interspecific comparisons of the growth performance. Nevertheless, Brickle et al. (2006) reported that $P$. ramsayi is a relatively slow-growing fish, with a maximum age of 14 years, and that males have lower growth rates and larger $T L$ than females. For the same geographic area, Brickle et al. (2005) described the growth of E. maclovinus and characterized it as a short-lived 

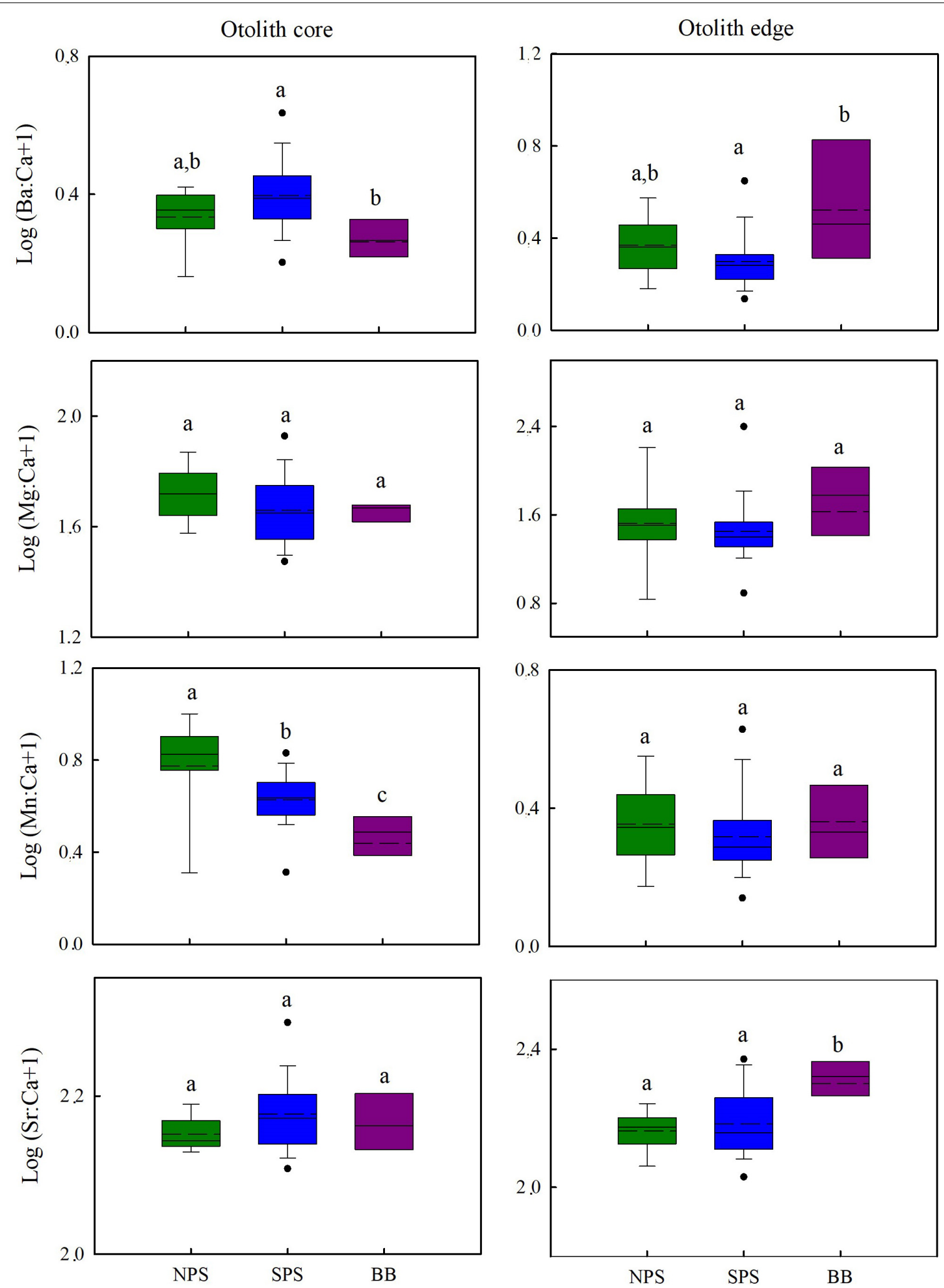

FIGURE 3 | Box plots showing the mean (dashed line), the median (solid line) and 25th and 75th percentiles of Ba:Ca, Mg:Ca, Mn:Ca, and Sr:Ca ratios for otolith core and edge areas of $C$. trigloides from the southwestern Atlantic Ocean. Different letters indicate significant differences among geographic areas. BB, Burdwood Bank; NPS, northern Patagonia shelf; SPS, southern Patagonia shelf. 
TABLE 4 | SIMPER analyses for the three groups of $C$. trigloides individuals identifying the most relevant element:Ca ratios responsible for the grouping for the core and edge areas of the otolith.

\begin{tabular}{|c|c|c|c|c|c|}
\hline Groups & Element:Ca ratios & Average value & Contribution \% & Cumulative \% & Average squared distance \\
\hline \multicolumn{6}{|c|}{ Otolith core } \\
\hline \multirow[t]{4}{*}{ NPS } & Sr:Ca & 2.15 & 1.52 & 1.52 & 0.03 \\
\hline & $\mathrm{Ba}: \mathrm{Ca}$ & 0.36 & 8.00 & 9.52 & \\
\hline & $\mathrm{Mg}: \mathrm{Ca}$ & 1.72 & 30.96 & 40.48 & \\
\hline & $\mathrm{Mn}: \mathrm{Ca}$ & 0.82 & 59.52 & 100.00 & \\
\hline \multirow[t]{4}{*}{ SPS } & $\mathrm{Sr}: \mathrm{Ca}$ & 2.18 & 6.07 & 6.07 & 0.04 \\
\hline & $\mathrm{Mn}: \mathrm{Ca}$ & 0.64 & 24.61 & 30.68 & \\
\hline & $\mathrm{Ba}: \mathrm{Ca}$ & 0.41 & 28.86 & 59.53 & \\
\hline & $\mathrm{Mg}: \mathrm{Ca}$ & 1.66 & 40.47 & 100.00 & \\
\hline \multirow[t]{4}{*}{ BB } & $\mathrm{Mg}: \mathrm{Ca}$ & 1.66 & 7.12 & 7.12 & 0.01 \\
\hline & Sr:Ca & 2.16 & 8.80 & 15.93 & \\
\hline & $\mathrm{Ba}: \mathrm{Ca}$ & 0.29 & 39.79 & 55.72 & \\
\hline & $\mathrm{Mn}: \mathrm{Ca}$ & 0.49 & 44.28 & 100.00 & \\
\hline \multicolumn{6}{|c|}{ Otolith edge } \\
\hline \multirow[t]{4}{*}{ NPS } & $\mathrm{Sr}: \mathrm{Ca}$ & 2.07 & 10.47 & 10.47 & 0.04 \\
\hline & Mn:Ca & 0.36 & 24.31 & 34.78 & \\
\hline & $\mathrm{Mg}: \mathrm{Ca}$ & 1.20 & 31.70 & 66.48 & \\
\hline & $\mathrm{Ba}: \mathrm{Ca}$ & 0.35 & 33.52 & 100.00 & \\
\hline \multirow[t]{4}{*}{ SPS } & Sr:Ca & 2.18 & 15.27 & 15.27 & 0.06 \\
\hline & $\mathrm{Ba}: \mathrm{Ca}$ & 0.29 & 19.74 & 35.01 & \\
\hline & $\mathrm{Mn}: \mathrm{Ca}$ & 0.33 & 25.35 & 60.37 & \\
\hline & $\mathrm{Mg}: \mathrm{Ca}$ & 1.42 & 39.63 & 100.00 & \\
\hline \multirow[t]{4}{*}{ BB } & $\mathrm{Sr}: \mathrm{Ca}$ & 2.34 & 1.44 & 1.44 & 0.12 \\
\hline & $\mathrm{Mn}: \mathrm{Ca}$ & 0.42 & 18.52 & 19.96 & \\
\hline & $\mathrm{Mg}: \mathrm{Ca}$ & 1.92 & 28.92 & 48.88 & \\
\hline & $\mathrm{Ba}: \mathrm{Ca}$ & 0.63 & 51.12 & 100.00 & \\
\hline
\end{tabular}

BB, Burdwood Bank; NPS, northern Patagonia shelf; SPS, southern Patagonia shelf.

species, attaining a maximum age of 11 years, with an average growth rate of $10.2 \mathrm{~cm} \mathrm{year}^{-1}$ for the first 6 years. In the central-southern Chilean coasts, Licandeo et al. (2006) found that the same species reached smaller sizes with a slower growth pattern. According to the maximum ages registered in other notothenioids from the same geographic area and the $T L_{\max }$ of C. trigloides $(\sim 80 \mathrm{~cm})$ registered by Lobao-Tello and Hüne (2012) and Arkhipkin et al. (2015), it is likely that older C. trigloides individuals will be found in Patagonian populations. A greater sample, encompassing a larger age range, would allow us to describe the growth of the species by applying the von Bertalanffy growth function and hence to support the intersex differences obtained from the back-calculated sizes. Moreover, the estimated parameters will allow comparison of the growth of notothenioids with different sizes through the growth performance index (Pauly and Munro, 1984). About it, Kock and Everson (1998) and La Mesa and Vacchi (2001) found that the growth performances of sub-Antarctic notothenioid species appear to be higher than those estimated for commercially harvested species from the seasonal pack-ice and the high Antarctic zones.

\section{Elemental Analysis}

In this study, the analysis of the chemical composition in C. trigloides otolith edges was an efficient approach to

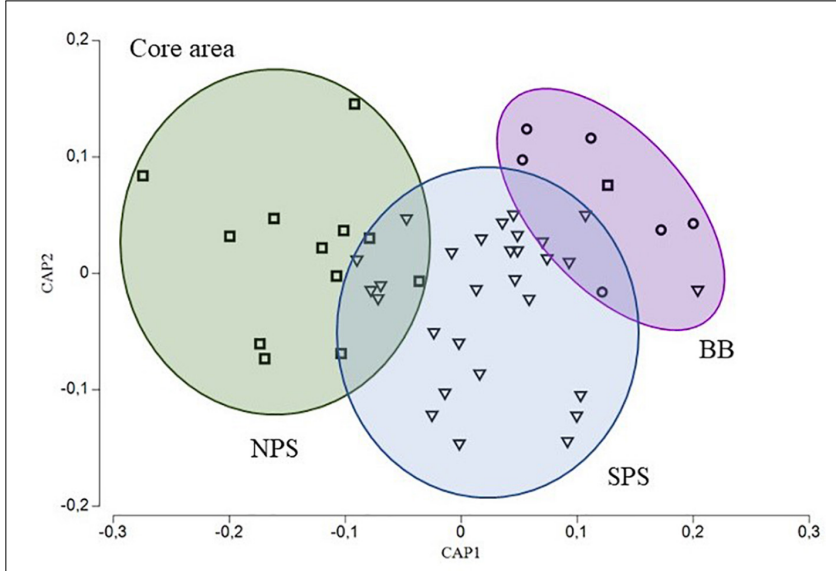

FIGURE 4 | CAP ordination diagram for $C$. trigloides based on the otolith chemical composition (Ba:Ca, Mg:Ca, Mn:Ca, and $\mathrm{Sr}: \mathrm{Ca}$ ) for the otolith core area. Geographical areas: northern Patagonia shelf (NPS, squares), southern Patagonia shelf (SPS, triangles), and Burdwood Bank (BB, circles).

discriminate among NPS, SPS, and BB areas, which suggests the possible existence of different stocks. Also, core analysis revealed marked segregation during the early stages of life for the 


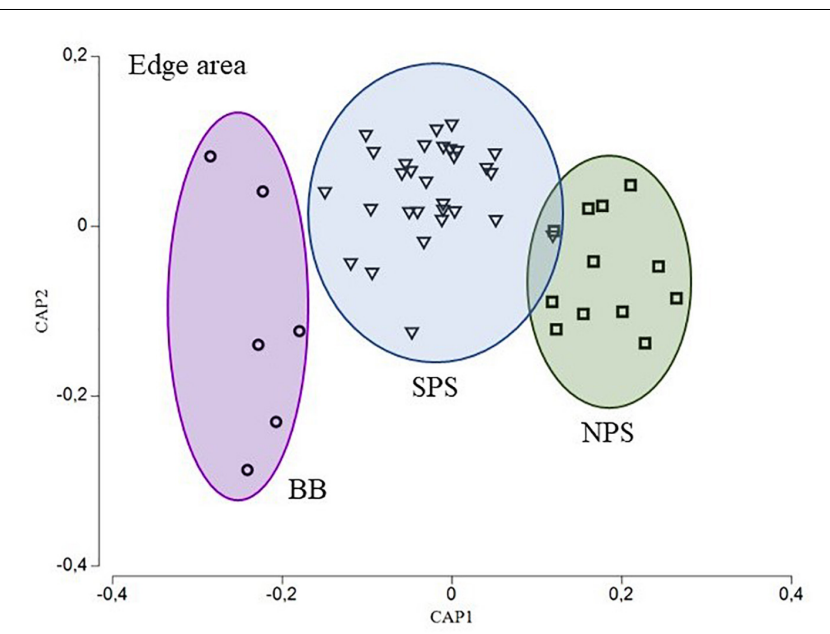

FIGURE 5 | CAP ordination diagram for $C$. trigloides based on the otolith chemical composition (Ba:Ca, Mg:Ca, Mn:Ca, and $\mathrm{Sr}: \mathrm{Ca}$ ) for the otolith edge area. Geographical areas: northern Patagonia shelf (NPS, squares), southern Patagonia shelf (SPS, triangles), and Burdwood Bank (BB, circles).

sampling sites, suggesting the existence of different nursery areas for NPS, SPS, and BB.

The similarities within these groups, identified throughout the ontogeny of $C$. trigloides, were mainly due to $\mathrm{Mn}: \mathrm{Ca}, \mathrm{Mg}: \mathrm{Ca}$, and $\mathrm{Ba}: \mathrm{Ca}$ ratios. Factors influencing the incorporation of trace elements into otolith calcium carbonate matrix are element and species specific, and can be related to environmental variables (Elsdon and Gillanders, 2003; Brown and Severin, 2009; Avigliano et al., 2019), genetics (Clarke et al., 2011), physiology (Sturrock et al., 2014, 2015), growth rate, and ontogeny (Walther et al., 2010), among others.

For instance, the otolith $\mathrm{Sr}$ :Ca ratio is usually positively correlated with salinity, while otolith $\mathrm{Ba}$ :Ca shows the opposite pattern (Martin and Thorrold, 2005; Brown and Severin, 2009; Avigliano et al., 2018b). Thus, these ratios have been used as habitat indicators in environments with salinity gradients, especially in diadromous fish (Albuquerque et al., 2010; Mai et al., 2014; Avigliano et al., 2017b). However, in several marine systems, where the salinity is relatively homogeneous, as observed in this study, otolith $\mathrm{Sr}: \mathrm{Ca}$ and $\mathrm{Ba}: \mathrm{Ca}$ can vary with other factors, such as temperature, water composition (mainly $\mathrm{Ba}$ ), genetics, ontogeny, and diet (Miller, 2009; DiMaria et al., 2010; Walther et al., 2010; Clarke et al., 2011). Specifically, Miller (2009) found a positive relationship between temperature and water concentration on the otolith incorporation of $\mathrm{Ba}: \mathrm{Ca}$ in juvenile black rockfish Sebastes melanops (Girard, 1856) under experimental conditions. Walther et al. (2010) found interactive effects between temperature, ontogeny (stage of the life history), and food quantity with otolith $\mathrm{Ba}: \mathrm{Ca}$, and significant interactions between stage and food with $\mathrm{Sr}: \mathrm{Ca}$ in the coral reef fish Acanthochromis polyacanthus (Bleeker, 1855). Moreover, DiMaria et al. (2010) described a negative relationship between $\mathrm{Sr}: \mathrm{Ca}$ and $\mathrm{Ba}: \mathrm{Ca}$ with temperature, and no relationship between $\mathrm{Mg}: \mathrm{Ca}$ and this environmental factor, in the Pacific cod Gadus macrocephalus (Tilesius, 1810). For that species, they suggested that the kinetic effects could be more important in the incorporation of $\mathrm{Sr}$ and $\mathrm{Ba}$ while metabolic effects would have a greater effect on the $\mathrm{Mg}$ incorporation. For the pelagic-neritic fish Menidia menidia (Linnaeus, 1766), a significant temperature effect on both Sr:Ca and Ba:Ca was reported (Clarke et al., 2011). Nevertheless, it turned out to be complex, not linear, and there was also an interaction with genetics (Clarke et al., 2011).

In addition, the coastal waters are richer in $\mathrm{Ba}$, due to the influence of water and continental sediments (Wolgemuth and Broecker, 1970). Unlike what happens with Sr, the levels of Ba in the ocean are not homogeneous and can vary both horizontally and vertically, especially in the Atlantic Ocean (Wolgemuth and Broecker, 1970). A Ba-enrichment was also reported in deep water, which reflects the uptake of $\mathrm{Ba}$ by the particles in the surface water and the subsequent release into deep waters (Wolgemuth and Broecker, 1970).

Concerning $\mathrm{Mn}: \mathrm{Ca}$, a relationship with environmental concentration was found in some species (Dorval et al., 2007; Mohan et al., 2012), while in others, it was not (Walther and Thorrold, 2008; Miller, 2009). It has been reported that the concentration of dissolved oxygen is negatively associated with $\mathrm{Mn}: \mathrm{Ca}$ in marine species such as the Atlantic cod Gadus morhua (Linnaeus, 1758), the European flounder Platichthys flesus (Linnaeus, 1758), the winter flounder Pseudopleuronectes americanus (Walbaum, 1792), and the Atlantic croaker Micropogonias undulatus (Linnaeus, 1766) (Mohan et al., 2014). The hypoxic or anoxic environments that are often associated with otolith Mn peaks are typically related to high depths (Limburg et al., 2015). This ratio also seems to be strongly associated with ontogenetic changes because a peak has been found in the otolith core of several marine species such as Dascyllus marginatus (Rüppell, 1829) (Ben-Tzvi et al., 2007), Sicydium punctatum (Perugia, 1896), and Sillaginodes punctatus (Cuvier, 1829) (Rogers et al., 2019).

In the present study, most of the sampling stations were located far from the coast, and only two sites with $C$. trigloides captures (13 and 15) could be associated with fresher subAntarctic waters (advected from Chile and entering the PS via Magellan and Le Maire Straits) around Tierra del Fuego Island. Nevertheless, salinity was relatively constant among sampling sites; therefore, the otolith $\mathrm{Ba}$ :Ca variation would not seem to be related to the proximity of continental water bodies. On the other hand, the heterogeneity in the bathymetry of the study area (Piola et al., 2018) could affect the concentration or bioavailability of element:Ca ratios (mainly Sr:Ca, Ba:Ca, and Mn:Ca) in water (Wolgemuth and Broecker, 1970; Limburg et al., 2015), and thus on their incorporation into the otolith, which should be particularly studied. Over the $\mathrm{PS}$, the temperature ranged up to $9.97^{\circ} \mathrm{C}$ between sampling stations and was more related to the depth than to latitude. Thus, we cannot rule out the potential effect of depth or some physicochemical parameters (i.e., temperature) on the element:Ca ratios responsible for the grouping.

Oceanographic phenomena could create barriers for fish populations and contribute to segregation, which could be reflected in the composition of otoliths (Cadrin et al., 2013; 
Wilson et al., 2018). Thus, we proposed that the circulation pattern in the PS and Burdwood Bank could also explain the multivariate differences found among areas. Numerical simulations suggested that the mean circulation over the PS consists of a broad northeastward flow that intensifies toward the outer shelf, with anticyclonic gyres and relatively weak poleward coastal currents within the Grande Bay and San Jorge Gulf (Palma et al., 2008; Combes and Matano, 2014; Piola et al., 2018). This circulation pattern may be the physical feature involved in maintaining the integrity of NPS and SPS nursery areas and fish stocks. A similar association between the existence of a geographically stable larval retention area for Sprattus fueguensis (Jenyns, 1842) and the anticyclonic current circulation and sinking of shelf waters in southern Patagonia was also indicated by Sánchez et al. (1995). Regarding BB, Matano et al. (2019) suggested that it is an active center for the obduction of deep, fertile waters to the surface layers of the Drake Passage. This phenomenon, which includes upwelling and mixing, is primarily driven by tides and strengthened by winter convection. According to numerical models, the resulting circulation patterns over the BB consists of a broad anticyclonic flow around the bank's rim and anticyclonic vortices on top of the interior seamounts that increase the retention of fluid parcels. Therefore, it could be contributing to the retention of $C$. trigloides individuals within the $\mathrm{BB}$ area. Moreover, considering that it is species living on or near the bottom, with adult males being territorial (Arkhipkin et al., 2015), low connectivity of individuals among different geographic areas could be expected.

Finally, the objective of this study was not to reveal the factors that influence the incorporation of elements into the $C$. trigloides otolith; however, this type of information could contribute to revealing the population structure with greater depth. In this sense, it is recommended to evaluate the relationship between different endogenous and exogenous factors in the incorporation of different elements. Moreover, future studies could incorporate other markers such as $\mathrm{Li}: \mathrm{Ca}, \mathrm{Cu}: \mathrm{Ca}, \mathrm{Rb}: \mathrm{Ca}, \mathrm{Zn}: \mathrm{Ca}$, and other methods such as genetics or otolith stable isotopes, which could also contribute to a better understanding of the observed differences over the PS.

\section{CONCLUSION}

This is the first time that the growth of $C$. trigloides has been described by using the Gompertz model, with males attaining larger sizes at faster growth rates. Moreover, the chemical analyses showed high segregation among the studied groups along the southwestern Atlantic Ocean, suggesting the presence

\section{REFERENCES}

Albuquerque, C. Q., Miekeley, N., and Muelbert, J. H. (2010). Whitemouth croaker, Micropogonias furnieri, trapped in a freshwater coastal lagoon: A natural comparison of freshwater and marine influences on otolith chemistry. Neotrop. Ichthyol. 8, 311-320. doi: 10.1590/S1679-6225201000020 0009 of different stocks and nursery areas. The information obtained regarding the growth and population structure of $C$. trigloides could provide new information, constituting an essential tool to develop conservation principles for the species.

\section{DATA AVAILABILITY STATEMENT}

The datasets generated for this study are available on request to the corresponding author.

\section{ETHICS STATEMENT}

As the Consejo Nacional de Investigaciones Cientificas y Técnicas (CONICET) does not possess formal committees regarding the fish welfare and sampling protocols, fish handling during sampling was performed following guidelines of the Ethical Committee of the UFAW Handbook on the Care and Management of Laboratory Animals (http://www.ufaw.org.uk).

\section{AUTHOR CONTRIBUTIONS}

ML conceived and wrote the manuscript, with contributions from $\mathrm{MB}$, and read the otoliths. FL and EA analyzed the data with contributions from ML. MR read the otoliths and contributed to age and growth analyses. ID prepared the otoliths for biochemical analyses. $\mathrm{CB}, \mathrm{FV}$, and DF participated in the research cruise and collected the fish samples. CA conducted the biochemical analyses. All authors contributed to the article and approved the submitted version.

\section{FUNDING}

This work was supported by the Consejo Nacional de Investigaciones Científicas y Técnicas (grant numbers PIP 0321, PIP 0440, and PUE 2016 - CADIC).

\section{ACKNOWLEDGMENTS}

The authors wish to thank S. Rimbau, D. Aureliano, and the crew of the Oceanographic Vessel Puerto Deseado for their technical assistance and Dr. Frank Sola for his assistance with the English language editing of the manuscript. Dr. Mario La Mesa and Daniel Brown are also acknowledged for their invaluable advice on the age and growth analyses.

Albuquerque, C. Q., Miekeley, N., Muelbert, J. H., Walther, B. D., and Jaureguizar, A. J. (2012). Estuarine dependency in a marine fish evaluated with otolith chemistry. Mar. Biol. 159, 2229-2239. doi: 10.1007/s00227-012-2007-5

Anderson, M. J., Gorley, R. N., and Clarke, K. R. (2008). PERMANOVA+ for PRIMER: Guide to Software and Statistical Methods. Plymouth: PRIMER-E.

Arkhipkin, A., Boucher, E., and Howes, P. N. (2015). Spawning and early ontogenesis in channel bull blenny Cottoperca gobio (Notothenioidei, 
Perciformes) caught off the Falkland Islands and maintained in captivity. Polar Biol. 38, 251-259. doi: 10.1007/s00300-014-1582-y

Ashford, J. R., Arkhipkin, A. I., and Jones, C. M. (2006). Can the chemistry of otolith nuclei determine population structure of Patagonian toothfish Dissostichus eleginoides? J. Fish Biol. 69, 708-721. doi: 10.1111/j.1095-8649. 2006.01144.x

Ashford, J. R., Jones, C. M., Hofmann, E., Everson, I., Moreno, C., Duhamel, G., et al. (2005). Can otolith elemental signatures record the capture site of patagonian toothfish (Dissostichus eleginoides), a fully marine fish in the Southern Ocean? Can. J. Fish. Aquat. Sci. 62, 2832-2840. doi: 10.1139/f0 $5-191$

Ashford, J. R., La Mesa, M., Fach, B., Jones, C., and Everson, I. (2010). Testing early life connectivity using otolith chemistry and particle-tracking simulations. Can. J. Fish. Aquat. Sci. 67, 1303-1315. doi: 10.1139/F10-065

Avigliano, E., Leisen, M., Romero, R., Carvalho, B., Velasco, G., Vianna, M., et al. (2017a). Fluvio-marine travelers from South America: cyclic amphidromy and freshwater residency, typical behaviors in Genidens barbus inferred by otolith chemistry. Fish. Res. 193, 184-194. doi: 10.1016/j.fishres.2017.04.011

Avigliano, E., Maichak de Carvalho, B., Leisen, M., Romero, R., Velasco, G., Vianna, M., et al. (2017b). Otolith edge fingerprints as an approach for stock identification of Genidens barbus. Estuar. Coast. Shelf Sci. 194, 92-96. doi: 10.1016/j.ecss.2017.06.008

Avigliano, E., Maichak de Carvalho, B., Miller, N., Córdoba Gironde, S., Tombari, A., Limburg, K., et al. (2019). Fin spines chemistry as a non-lethal alternative to otoliths for habitat and stock discrimination: comparison between structures for an endangered catfish species. Mar. Ecol. Prog. Ser. 614, 147-157. doi: $10.3354 /$ meps 12895

Avigliano, E., Miller, N., and Volpedo, A. V. (2018a). Silversides (Odontesthes bonariensis) reside within freshwater and estuarine habitats, not marine environments. Estuar. Coast. Shelf. Sci. 205, 123-130. doi: 10.1016/j.ecss.2018. 03.014

Avigliano, E., Pisonero, J., Dománico, A., Silva, N., Sánchez, S., and Volpedo, A. V. (2018b). Spatial segregation and connectivity in young and adult stages of Megaleporinus obtusidens inferred from otolith elemental signatures: implications for managment. Fish. Res. 204, 239-244. doi: 10.1016/j.fishres. 2018.03.007

Balushkin, A. V. (2000). Morphology, classification, and evolution of notothenioid fishes of the Southern Ocean (Notothenioidei, Perciformes). J. Ichthyol. 40, 74-109.

Beamish, R. J., and Fournier, D. A. (1981). A method for comparing the precision of a set of age determinations. Can. J. Fish. Aquat. Sci. 38, 982-983. doi: 10.1139/ f81-132

Ben-Tzvi, O., Abelson, A., Gaines, S. D., Sheehy, M. S., Paradis, G. L., and Kiflawi, M. (2007). The inclusion of sub-detection limit LA-ICPMS data, in the analysis of otolith microchemistry, by use of a palindrome sequence analysis (PaSA). Limnol. Oceanogr. Methods 95, 97-105. doi: 10.4319/lom.2007.5.97

Biolé, F. G., Thompson, G. A., Vargas, C. V., Leisen, M., Barra, F., Volpedo, A. V., et al. (2019). Fish stocks of Urophycis brasiliensis revealed by otolith fingerprint and shape in the Southwestern Atlantic Ocean. Estuar. Coast. Shelf Sci. 229:106406. doi: 10.1016/j.ecss.2019.106406

Brazner, J. C., Campana, S. E., Tanner, D. K., and Schram, S. T. (2004). Reconstructing habitat use and wetland nursery origin of yellow perch from Lake Superior using otolith elemental analysis. J. Great Lakes Res. 30, 492-507. doi: 10.1016/S0380-1330(04)70365-2

Brickle, P., Arkhipkin, I., and Shcherbich, Z. N. (2005). Age and growth in a temperate euryhaline notothenioid, Eleginops maclovinus from the Falklands Islands. J. Mar. Biol. Ass. U.K. 85, 1217-1221. doi: 10.1017/S0025315405012348

Brickle, P., Arkhipkin, I., and Shcherbich, Z. N. (2006). Age and growth of a subAntarctic notothenioid, Patagonotothen ramsayi (Regan 1913), from Falklands Islands. Polar Biol. 29, 633-639. doi: 10.1007/s00300-005-0099-9

Brown, R. J., and Severin, K. P. (2009). Otolith chemistry analyses indicate that water $\mathrm{Sr}: \mathrm{Ca}$ is the primary factor influencing otolith $\mathrm{Sr}: \mathrm{Ca}$ for freshwater and diadromous fish but not for marine fish. Can. J. Fish. Aquat. Sci. 66, 1790-1808. doi: $10.1139 / \mathrm{F} 09-112$

Cadrin, S. X., Karr, L. A., and Mariani, S. (2013). "Stock identification methods: an overview," in Stock Identification Methods. Applications in Fishery Science, eds S. X. Cadrin, L. A. Kerr, and S. Mariani (Woods Hole, MA: Academic Press), 3-6. doi: 10.1016/b978-012154351-8/50002-2
Campana, S. E. (1990). How reliable are growth back-calculations based on otoliths? Can. J. Fish. Aquat. Sci. 47, 2219-2227. doi: 10.1139/f90-246

Campana, S. E. (1999). Chemistry and composition of fish otoliths: pathways, mechanisms and applications. Mar. Ecol. Prog. Ser. 188, 263-297. doi: 10.3354/ meps 188263

Campana, S. E. (2001). Accuracy, precision and quality control in age determination, including a review of the use and abuse of age validation methods. J. Fish Biol. 59, 197-242. doi: 10.1111/j.1095-8649.2001.tb00127.x

Campana, S. E. (2014). "Otolith elemental as a natural marker of fish stocks," in Stock Identification Methods: Applications in Fishery, eds S. X. Cadrin, L. A. Kerr, and S. Mariani (Amsterdam: Elsevier), 227-245. doi: 10.1017/ S002531541900016X

Campana, S. E., Thorrold, S. R., Jones, C. M., Gunther, D., Tubrett, M., Longerich, H., et al. (1997). Comparison of accuracy, precision and sensitivity in elemental assays of fish otoliths using the electron microprobe, proton-induced X-ray emission, and laser ablation inductively coupled plasma mass spectrometry. Can. J. Fish. Aquat. Sci. 54, 2068-2079. doi: 10.1139/cjfas-54-9-2068

Carvalho, B. M., Volpedo, A. V., Vaz-dos-Santos, A. M., and Spach, H. L. (2017). Use of otolith microchemistry as habitat indicator of Anchoa tricolor (Spix \& Agassiz, 1829) in a subtropical estuary. Lat. Am. J. Aquat. Res. 45, 457-465. doi: $10.3856 /$ vol45-issue2-fulltext- 20

Catalán, I. A., Alós, J., Díaz-Gil, C., Pérez-Mayol, S., Basterretxea, G., Morales-Nin, B., et al. (2018). Potential fishing-related effects on fish life history revealed by otolith microchemistry. Fish. Res. 199, 186-195. doi: 10.1016/j.fishres.2017.11. 008

Chang, W. Y. B. (1982). A statistical method for evaluating the reproducibility of age determination. Can. J. Fish. Aquat. Sci. 39, 1208-1210. doi: 10.1139/f82- 158

Clarke, K. R., Gorley, R. N., Somerfield, P. J., and Warwick, R. M. (2014). Change in Marine Communities: An Approach to Statistical Analysis and Interpretation, 3rd Edn. Plymouth: PRIMER-E.

Clarke, L. M., Conover, D. O., and Thorrold, S. R. (2011). Population differences in otolith chemistry have a genetic basis in Menidia menidia. Can. J. Fish. Aquat. Sci. 68, 105-114. doi: 10.1139/F10- 147

Colombo, M., Damerau, M., Hanel, R., Salzburger, W., and Matschiner, M. (2015). Diversity and disparity through time in the adaptive radiation of Antarctic notothenioid fishes. J. Evol. Biol. 28, 376-394. doi: 10.1111/jeb.12570

Combes, V., and Matano, R. P. (2014). A two-way nested simulation of the oceanic circulation in the Southwestern Atlantic. J. Geophys. Res. Oceans 119, 731-756. doi: 10.1002/2013jc009498

Coppola, D., Giordano, D., Vergara, A., Mazzarella, L., di Prisco, G., Verde, C., et al. (2010). The hemoglobins of sub-Antarctic fishes of the suborder Notothenioidei. Polar Sci. 4, 295-308. doi: 10.1016/j.polar.2010.04.007

DiMaria, R. A., Miller, J. A., and Hurst, T. P. (2010). Temperature and growth effects on otolith elemental chemistry of larval Pacific cod, Gadus macrocephalus. Environ. Biol. Fish 89, 453-462. doi: 10.1007/s10641-010-96652

Dorval, E., Jones, C. M., Hannigan, R., and Montfrans, J. V. (2007). Relating otolith chemistry to surface water chemistry in a coastal plain estuary. Can. J. Fish. Aquat. Sci. 64, 411-424. doi: 10.1139/f07-015

Eastman, J. T. (1993). Antarctic Fish Biology: Evolution in a Unique Environment. San Diego, CA: Academic Press.

Eastman, J. T., Witmer, L. M., Ridgely, R. C., and Kuhn, K. L. (2014). Divergence in skeletal mass and bone morphology in Antarctic notothenioid fishes. J. Morphol. 275, 841-861. doi: 10.1002/jmor.20258

Elsdon, T. S., and Gillanders, B. M. (2003). Relationship between water and otolith elemental concentrations in juvenile black bream Acanthopagrus butcheri. Mar. Ecol. Prog. Ser. 260, 263-272. doi: 10.3354/meps260263

Falkland Islands Government [FIG] (2019). Fisheries Department Fisheries Statistics, 23. Stanley: FIG Fisheries Department.

Fernández, D. A., Bruno, D. O., and Llompart, F. M. (2018). Length-weight relationship of six notothenioid species from sub-Antarctic waters (Beagle Channel, Argentina). J. Appl. Ichthyol. 35, 597-599. doi: 10.1111/jai.13833

Fernández, D. A., Ceballos, S. G., Malanga, G., Boy, C. C., and Vanella, F. A. (2012). Buoyancy of sub-Antarctic notothenioids including the sister lineage of all other notothenioids (Bovichtidae). Polar Biol. 35, 99-106. doi: 10.1007/s00300-0111037-7

Fernández, D. A., Lattuca, M. E., Boy, C. C., Pérez, A. F., Cevallos, S. G., Vanella, F. A., et al. (2009). Total energy content and energy densities of the main tissues 
of Sub-Antarctic fishes from the Beagle Channel. Fish Physiol. Biochem. 35, 181-188. doi: 10.1007/s10695-008-9234-1

Froese, R., and Binohlan, C. (2000). Empirical relationships to estimate asymptotic length, length at first maturity and length at maximum yield per recruit in fishes, with a simple method to evaluate length frequency data. J. Fish Biol. 56, 758-773. doi: 10.1006/jfbi.1999.1194

Geffen, A. J., Morales-Nin, B., Pérez-Mayol, S., Cantarero-Roldán, A. M., Skadal, J., and Tovar-Sánchez, A. (2013). Chemical analysis of otoliths: cross validation between techniques and laboratories. Fish. Res. 143, 67-80. doi: 10.1016/j. fishres.2013.01.005

Giordano, D., Boechi, L., Vergara, A., Martí, M. A., Samuni, U., Dantsker, D., et al. (2008). The hemoglobins of the sub-Antarctic fish Cottoperca gobio, a phyletically basal species - oxygen-binding equilibria, kinetics and molecular dynamics. FEBS J. 276, 2266-2277. doi: 10.1111/j.1742-4658.2009.06954.x

Gompertz, B. (1825). On the nature of the function expressive of the law of human mortality, and on a new mode of determining the value of life contingencies. Phil. Trans. R. Soc. Lond. 115, 513-583. doi: 10.1098/rstl.1825.0026

Gon, O., and Heemstra, P. C. (1990). Fishes of the Southern Ocean. Grahamstown: J. L. B. Smith Institute of Ichthyology.

Henderson, P. A., and Seaby, R. M. (2006). Growth II. Lymington: Pisces Conservation Ltd.

Iwami, T. (2004). Comparative morphology of the adductor mandibulae musculature of notothenioid fishes (Pisces. Perciformes). Antarct. Sci. 16, 17-21. doi: 10.1017/S0954102004001762

Jackson, S. (2008). Calibration strategies for elemental analysis by LA-ICP-MS" in Mineralogical Association of Canada Short Course. Vancouver 40, 169-188.

Kock, K.-H., and Everson, I. (1998). "Age, growth and maximum size of Antarctic notothenioid fish - Revisited," in Fishes of Antarctica. A biological review, eds G. di Prisco, E. Pisano, and A. Clarke (Italy: Springer-Verlag), 29-40. doi: 10.1007/978-88-470-2157-0_2

La Mesa, M., and Vacchi, M. (2001). Age and growth of high Antarctic notothenioid fish. Antart. Sci. 13, 227-235. doi: 10.1017/s0954102001000335

Laptikhovsky, V. V., and Arkhipkin, A. I. (2003). An impact of seasonal squid migrations and fishing on the feeding spectra of subantarctic notothenioids Patagonotothen ramsayi and Cottoperca gobio around the Falkland Islands. J. Appl. Ichthyol. 19, 35-39. doi: 10.1046/j.1439-0426.2003.00340.x

Licandeo, R. R., Barrientos, C. A., and González, M. T. (2006). Age, growth rates, sex change and feeding habits of notothenioid fish Eleginops maclovinus from the central-southern Chilean coast. Environ. Biol. Fish. 77, 51-61. doi: 10.1007/ s10641-006-9054-z

Limburg, K. E., Walther, B. D., Lu, Z., Jackman, G., Mohan, J., Walther, Y., et al. (2015). In search of the dead zone: Use of otoliths for tracking fish exposure to hypoxia. J. Mar. Syst. 141, 167-178. doi: 10.1016/j.jmarsys.2014.02.014

Lin, J., Liu, Y., Yang, Y., and Hu, Z. (2016). Calibration and correction of LA-ICPMS and LA-MC-ICP-MS analyses for element contents and isotopic ratios. Solid Earth Sci. 1, 5-27. doi: 10.1016/j.sesci.2016.04.002

Lloris, D., and Rucabado, J. (1991). Ictiofauna del Canal Beagle (Tierra de Fuego), aspectos ecológicos y análisis biogeográfico. Publicación Especial del Instituto Español de Oceanografía 8:182.

Lobao-Tello, P. R., and Hüne, M. (2012). Peces del Sur de Chile. Santiago, CA: Fundación Ictiológica.

Mai, A. C. G., Condini, M. V., Albuquerque, C. Q., Loebmann, D., Saint'Pierre, T. D., Miekeley, N., et al. (2014). High plasticity in habitat use of Lycengraulis grossidens (Clupeiformes. Engraulididae). Est. Coast. Shelf. Sci. 141, 17-25. doi: 10.1016/j.ecss.2014.01.014

Martin, G. B., and Thorrold, S. R. (2005). Temperature and salinity effects on magnesium, manganese, and barium incorporation in otoliths of larval and early juvenile spot Leiostomus xanthurus. Mar. Ecol. Prog. Ser. 293, 223-232. doi: $10.3354 /$ meps 293223

Matallanas, J. (1988). Datos morfológicos y morfométricos del tracto alimentario de peces del Canal de Beagle. Misc. Zool. 12, 237-243.

Matano, R. P., Palma, E. D., and Combes, V. (2019). The Burdwood Bank circulation. J. Geophys. Res. Oceans 124, 6904-6926. doi: 10.1029/ 2019JC015001

Miller, J. A. (2009). The effects of temperature and water concentration on the otolith incorporation of barium and manganese in black rockfish Sebastes melanops. J. Fish Biol. 75, 39-60. doi: 10.1111/j.1095-8649.2009.02262.x
Mohan, J., Rahman, M. S., Thomas, P., and Walther, B. (2014). Influence of constant and periodic experimental hypoxic stress on Atlantic croaker otolith chemistry. Aquat. Biol. 1, 1-11. doi: 10.3354/ab00542

Mohan, J. A., Rulifson, R. A., Reide Corbett, D., and Halden, N. M. (2012). Validation of oligohaline elemental otolith signatures of striped bass by use of in situ caging experiments and water chemistry. Mar. Coast. Fish. 4, 57-70. doi: $10.1080 / 19425120.2012 .656533$

Moreno, C. A., and Jara, H. F. (1984). Ecological studies on fish fauna associated with Macrocystis pyrifera belts in the south of Fueguian Islands. Chile. Mar. Ecol. Progr. Ser. 15, 99-107. doi: 10.3354/meps015099

NIST (1990). Certificate Analysis. Standard Reference Material NIST1834. Gaithersburg: National Institute of Standards and Technology.

Palma, E. D., Matano, R. P., and Piola, A. R. (2008). A numerical study of the southwestern Atlantic shelf circulation: stratified ocean response to local and offshore forcing. J. Geophys. Res. Oceans 113:C11010. doi: 10.1029/ 2007JC004720

Papetti, C., Windisch, H. S., La Mesa, M., Lucassen, M., Marshall, C., and Lamare, M. D. (2016). Non-Antarctic notothenioids: Past phylogenetic history and contemporary phylogeographic implications in the face of environmental changes. Mar. Genom. 25, 1-9. doi: 10.1016/j.margen.2015.11.007

Pauly, D., and Munro, J. L. (1984). Once more on the comparison of growth in fishes and invertebrates. Fishbyte 2:21.

Piola, A. R., Palma, E. D., Bianchi, A. A., Castro, M., Dottori, M., Guerrero, R. A., et al. (2018). "Physical oceanography of the SW Atlantic Shelf: a review," in Plankton Ecology of the Southwestern Atlantic, eds M. S. Hoffmeyer, M. E. Sabatini, F. P. Brandini, D. L. Calliari, and N. H. Santinelli (Cham: Springer International Publishing AG), 37-56. doi: 10.1007/978-3-319-77869-3_2

Radigan, W. J., Carlson, A. K., Fincel, M. J., and Graeb, B. D. S. (2018). Otolith chemistry as a fisheries management tool after flooding: The case of Missouri River gizzard shad. River Res. Appl. 34, 270-278. doi: 10.1002/rra.3247

Radtke, R., Hubold, G., Folsom, S., and Lenz, P. (1993). Otolith structural and chemical analyses: the key to resolving age and growth of the Antarctic silverfish, Pleuragramma antarcticum. Antarct. Sci. 5, 51-62. doi: 10.1017/ S0954102093000082

Radtke, R. L., and Targett, T. E. (1984). Rhythmic structural and chemical patterns in otoliths of the Antarctic fish Notothenia larseni: Their application to age determination. Polar Biol. 3, 203-210. doi: 10.1007/bf00292624

Ricker, W. (1979). "Growth rates and models," in Fish Physiology. Volume VIII; Bioenergetics and Growth, eds W. Hoar, D. Randall, and J. Brett (New York, NY: Academic Press), 677-743. doi: 10.1016/S1546-5098(08)60034-5

Rogers, T. A., Fowler, A. J., Steer, M. A., and Gillanders, B. M. (2019). Discriminating natal source populations of a temperate marine fish using larval otolith chemistry. Front. Mar. Sci. 6:711. doi: 10.3389/fmars.2019.00711

Sánchez, R. P., Remeslo, A., Madirolas, A., and Ciechomski, J. D. (1995). Distribution and abundance of post-larvae and juveniles of the Patagonian sprat, Sprattus fueguensis, and related hydrographic conditions. Fish. Res. 23, 47-81. doi: 10.1016/0165-7836(94)00339-x

Schetjer, L., Rimondino, C., Chiesa, I., Astarloa, J., Doti, B., Elias, R., et al. (2016). Namuncurá marine protected area: An oceanic hotspot of benthic biodiversity at Burdwood Bank. Argentina. Polar Biol. 39, 2372-2386. doi: 10.1007/s00300016-1913-2

Soeth, M., Spach, H. L., Daros, F. A., Adelir-Alves, J., de Almeida, A. C. O., and Correia, A. T. (2019). Stock structure of Atlantic spadefish Chaetodipterus faber from Southwest Atlantic Ocean inferred from otolith elemental and shape signatures. Fish. Res. 211, 81-90. doi: 10.1016/j.fishres.2018.11.003

Sokal, R. R., and Rohlf, F. J. (2011). Biometry: The Principles and Practice of Statistics in Biological Research, 2nd Edn. New York, NY: W. H. Freeman, doi: $10.2307 / 2343822$

Sturrock, A. M., Hunter, E., Milton, J. A., Johnson, R. C., Waring, C. P., and Trueman, C. N. (2015). Quantifying physiological influences on otolith microchemistry. Methods Ecol. Evol. 6, 806-816. doi: 10.1111/2041-210X.12381

Sturrock, A. M., Trueman, C. N., Milton, J. A., Waring, C. P., Cooper, M. J., and Hunter, E. (2014). Physiological influences can outweigh environmental signals in otolith microchemistry research. Mar. Ecol. Prog. Ser. 500, 245-264. doi: 10.3354/meps10699

Takagi, Y., and Takahashi, A. (1999). Characterization of otolith soluble-matrix producing cells in the saccular epithelium of rainbow trout (Oncorhynchus 
mykiss) inner ear. Anat. Rec. 254, 322-329. doi: 10.1002/(SICI)10970185(19990301)254:3<322::AID-AR2<3.0.CO;2-Q

Tanner, S. E., Reis-Santos, P., and Cabral, H. N. (2016). Otolith chemistry in stock delineation: A brief overview, current challenges and future prospects. Fish. Res. 173, 206-213. doi: 10.1016/j.fishres.2015.07.019

Thomas, O. R. B., Ganio, K., Roberts, B. R., and Swearer, S. E. (2017). Trace element-protein interactions in endolymph from the inner ear of fish: implications for environmental reconstructions using fish otolith chemistry. Metallomics 9, 239-224. doi: 10.1039/c6mt00189k

Thomas, O. R. B., and Swearer, S. E. (2019). Otolith biochemistry - a review. Rev. Fish. Sci. Aquac. 27, 458-489. doi: 10.1080/23308249.2019.162 7285

Thresher, R. E. (1999). Elemental composition of otoliths as a stock delineator in fishes. Fish. Res. 43, 165-204. doi: 10.1016/S0165-7836(99)00 072-7

Vanella, F. A., Fernaindez, D. A., Romero, M. C., and Calvo, J. (2007). Changes in the fish fauna associated with a sub-Antarctic Macrocystis pyrifera kelp forest in response to canopy removal. Polar Biol. 30, 449-457. doi: 10.1007/s00300-0060202-x

Volpedo, A., and Fernández Cirelli, A. (2006). Otolith chemical composition as a useful tool for sciaenids stock discrimination in Southwestern Atlantic. Sci. Mar. 70, 325-334. doi: 10.3989/scimar.2006.70n2325

Walther, B. D., Kingsford, M. J., O'Callaghan, M. D., and McCulloch, M. T. (2010). Interactive effects of ontogeny, food ration and temperature on elemental incorporation in otoliths of a coral reef fish. Environ. Biol. Fish 89, 441-451. doi: 10.1007/s10641-010-9661-6
Walther, B. D., and Limburg, K. E. (2012). The use of otolith chemistry to characterize diadromous migrations. J. Fish Biol. 81, 796-825. doi: 10.1111/j. 1095-8649.2012.03371.x

Walther, B. D., and Thorrold, S. R. (2008). Continental-scale variation in otolith geochemistry of juvenile American shad (Alosa sapidissima). Can. J. Fish. Aquat. Sci. 65, 2623-2635. doi: 10.1139/F08-164

Wilson, M. T., Dougherty, A., Matta, M. E., Mier, K. L., and Miller, J. A. (2018). Otolith chemistry of juvenile walleye pollock Gadus chalcogrammus in relation to regional hydrography: evidence of spatially split cohorts. Mar. Ecol. Prog. Ser. 588, 163-178. doi: 10.3354/meps 12425

Wolgemuth, K., and Broecker, W. S. (1970). Barium in seawater. Earth Planet. Sci. Lett. 8, 372-378. doi: 10.1016/0012-821X(70)90110-X

Zar, J. H. (1984). Biostatistical Analysis. New Jersey: Prentice-Hall International Editions.

Conflict of Interest: The authors declare that the research was conducted in the absence of any commercial or financial relationships that could be construed as a potential conflict of interest.

Copyright (C) 2020 Lattuca, Llompart, Avigliano, Renzi, De Leva, Boy, Vanella, Barrantes, Fernández and de Albuquerque. This is an open-access article distributed under the terms of the Creative Commons Attribution License (CC BY). The use, distribution or reproduction in other forums is permitted, provided the original author(s) and the copyright owner(s) are credited and that the original publication in this journal is cited, in accordance with accepted academic practice. No use, distribution or reproduction is permitted which does not comply with these terms. 